\title{
Arms, corruption, and the state: Understanding the role of arms trade corruption in power politics
}

\section{Sam Perlo-Freeman}

Sam Perlo-Freeman is Program Manager, Global Arms and Corruption, World Peace Foundation, Fletcher School of Law and Diplomacy, Tufts University, Boston, MA, USA, where he may be reached at Samuel.Perlo_Freeman@tufts.edu. He also is Research Coordinator, Campaign Against Arms Trade, United Kingdom, and can be reached there at Sam@caat.org.uk.

\section{Abstract}

This article discusses patterns of corruption in the arms business around the world. It finds corruption to be widespread, almost ubiquitous in some sectors such as submarines, and affecting developed democracies as recipients as much as other countries. Anti-corruption efforts face severe challenges in proving corruption in highly complex financial cases involving multiple jurisdictions. However, they also face obstruction from exporter governments who are reluctant to prosecute their national defense industry champions so that even where investigations bear fruit, companies tend to receive light treatment. The article argues that corruption in the arms trade is not merely and simply a matter of individual and corporate greed, but is, on the seller's side, also an element of defense industrial policy as countries seek to maintain advanced technological capabilities in the face of limited domestic demand, widespread international competition, and a buyer's market. For recipients in buyer, and sometimes also seller, countries, an underemphasized aspect is the role of arms trade corruption as a means of securing political finance by senior politicians involved in decisionmaking. Thus, the practice occupies a systemic role in political competition, complicating efforts to tackle it.

$\mathrm{T}$ hat the international arms trade is particularly susceptible to corruption has long been recognized. Factors such as the high value and complexity of deals, and the level of secrecy shrouding the arms business all help provide means, motive, and opportunity to politicians, bureaucrats, and military officers to profit from arms deals, and for arms exporting companies to seek to swing deals in their favor. ${ }^{1}$

This article argues that corruption in the arms business is not merely and simply a matter of opportunity for personal enrichment, but is closely connected to the pursuit and practice of political power at both the buyer's and seller's ends, and to the national security interests of exporting states. This makes corruption in the arms business a tough "nut to crack" in the sense that the vested interests in preserving corruption are systemic and are tied to long-standing institutions of state power and politics rather than just the greed of individuals.

The analysis is based on the work conducted over the past two years by the World Peace Foundation's (WPF) program on Global Arms and Corruption, in particular its Compendium of Arms Trade Corruption, a collection of currently 29 cases of corruption in the arms trade and the broader military sector. The article presents a summary of the results of this work, discusses some of the lessons learned about the scope and nature of arms trade corruption, and then explores more deeply the underlying political economic factors driving arms trade corruption.

The next section briefly presents the Compendium as it stands and discusses pending cases that may be included in the near future. It also discusses patterns of corruption in the global arms trade as revealed by the Compendium and the broader work of WPF's Global Arms and Corruption project. The section thereafter discusses corruption in the arms trade from the seller's perspective in the context of a crowded international arms market where exporters (sellers) are willing to turn a blind eye to corruption as a means of maintaining a defense industrial base in their home country. This is followed by a section that considers the relation between arms trade corruption and domestic political power plays in both buyer and seller countries and how such corruption is often closely linked to political finance. The last section concludes. ${ }^{2}$

Patterns of corruption in the arms trade

The arms trade is widely recognized as one of the most corrupt areas of legal international trade worldwide. In 2005, anti-corruption researcher Joe Roeber estimated, based on a review of U.S. corruption complaints, that 40 percent of corruption in international trade was arms trade-related. Andrew Feinstein in The Shadow World describes a pattern of systematic corruption in the arms trade, with numerous examples. More recently, Transparency International's (TI) 
Government Defence Anti-Corruption Index shows that, due to a lack of transparency and accountability in their budgeting and procurement processes and their operational practices, most of the world's leading arms importers have High to Critical ratings for the vulnerability of their military sector to corruption. It should be noted that corruption in the military sector goes well beyond arms procurement. Senior commanders appropriate salaries of nonexistent "ghost" soldiers, divert arms and equipment through illegal sales, sell promotions, award fake supply contracts to businesses run by friends and family, and much more. These are common problems in many militaries. In war contexts such as Afghanistan and Nigeria, this can have a devastating effect on military effectiveness, contribute to human rights abuses, and have a prolonging effect on conflict. ${ }^{3}$

Several key factors are frequently presented as reasons why the arms trade, and the military sector more broadly, are particularly susceptible to corruption. First is the degree of secrecy that frequently surrounds defense and security matters in general and major arms deals in particular. The military budget is often the least transparent area of the state budget. Parliament and civil society often have limited access to information and frequently are discouraged or prevented from holding the government to account on defense matters. Even in western democracies that are typically more transparent, the details of major procurement tenders may be restricted due to national security and/or commercial confidentiality issues. In some countries the military have de jure or de facto immunity, or near-immunity, from corruption investigations, leaving authorities unable to conduct meaningful investigations.

Second, and more specific to the arms trade, is the huge value of individual deals for major weapons systems such as combat aircraft, warships, and submarines. Often once-in-a-generation purchases, they represent a large potential win for exporters and an enormous potential bounty for corrupt officials or politicians on the importer side even when only a small percentage in "commissions" (that is, bribes) is in play. This gives a powerful motivation for corruption on both the buyer and seller side as explored in later sections below.

Third, major arms deals are often highly complex and technical affairs with only a handful of people on the buyer's end understanding or even knowing the details of a tender, making procurement requirements vulnerable to manipulation if key individuals are bribed. Moreover, major arms deals are highly customized: A variety of subsystems and weaponry are included as part of the deal, along with long-term maintenance, training, and offsets packages, the latter involving investments, subcontracting, and countertrade with the buyer country on the part of the seller company. This means that there is no clear
This article argues that corruption in the global arms trade is not simply a matter of individual and/or corporate greed, but is, on the seller's side, an element of defense industrial policy as countries seek to maintain advanced technological capabilities in the face of limited domestic demand, widespread international competition, and a buyer's market. For recipients in buyer, and sometimes also seller, countries, an underemphasized aspect is the role of arms trade corruption as a means of securing political finance by senior politicians involved in decisionmaking. Thus, the practice occupies a systemic role in political competition, complicating efforts to tackle it.

price for a given weapon system so that commission payments can readily be hidden in the overall price of the package.

Finally, offsets specifically are themselves a major source of corruption. Typically open to even less scrutiny than the underlying arms deals, due to commercial confidentiality, the investments and contracts resulting from offset packages can offer a major boon to businesses in the buyer country, and to their shareholders, allowing decisionmakers to direct offsets toward items that will benefit themselves or their friends and family. While offsets occur in other areas of government procurement, they are most prominent in the arms trade, largely due to the national security exemptions in the WTO Agreement on Government Procurement of 1994, and other international trade agreements, which otherwise prohibit offsets. ${ }^{4}$

In its Compendium, WPF has so far collected 29 cases of arms trade and broader military corruption. These are set out in a standard format providing key details of each deal such as buyer, seller, equipment sold, price, and the amount involved in the corruption allegations, along with a narrative description of the deal, the corruption, and the investigations that have taken place. The work is being expanded. The cases do not constitute a systematic or representative sample, but through the research WPF has conducted into these and other cases it is possible to gain some further insights into the nature, scope, and political driving forces that lie behind arms trade corruption.

\section{The scale and scope of arms trade corruption}

To no one's surprise, WPF finds that there is indeed plenty of corruption in the arms trade. The 29 cases in the Compendium represent to some degree the proverbial tip of the iceberg and additional cases have been found in country studies of Indonesia, Russia, and India. Moreover, the Compendium covers only those cases that have been the subject of serious investigations where significant evidence of corruption has emerged (although convictions have not always followed). 
In some sectors, the prevalence of cases suggests that corruption may be routine. The sale of submarines, chiefly by France and Germany (the U.K. and the U.S. produce only nuclear-powered submarines and do not export them), is the subject of no less than 8 cases in a fairly small universe of contracts for these major platforms. Major combat aircraft sales from Europe also appear to be a sector where a high proportion of deals have been the subject of serious corruption cases, in particular where BAE Systems has been involved, through its established network of agents and financial shell companies.

The systematic, routine nature of bribery in some sectors is illustrated with an anecdote from Jean Guisnel's book, Armes de corruption massive. Guisnel describes a raid in 2008 at the offices of the French naval manufacturer DCNS, the company involved in the French submarine sales in question (as well as surface ships). The raid found a notebook from the company's former finance director in which he describes the processes by which DCNS vessels were marketed. He remarks that between 1991 and 2002, DCNS sold 60 billion francs-worth of vessels (EUR9.15 billion), of which 8 to 10 percent-thus around 732 million to 915 million euros-were paid in Frais Commerciaux Exceptionelles (or FCE, that is, Exceptional Commercial Expenses). These payments went to agents and lobbyists who redistributed them to their ultimate beneficiaries. FCE was the term given to commission payments, in other words bribes, that until France's accession to the OECD Convention on Corruption in 1999 were not only legal but tax-deductible. Moreover, in some of the cases from the 1990s assembled in the Compendium, the payment of such commissions was charged to the French state arms export agency, SOFRIMA, so normal and routine was the practice. ${ }^{5}$

Of course, the direct involvement of state agencies could no longer continue after the signing of the OECD convention, so since then French companies have had to use their own networks to pay commissions, where they have done so. There is no indication that the practice of paying commissions/bribes by European arms sellers has ceased as a result of the Convention. Of the cases in the Compendium, 14 involve sales by European countries after the Convention entered into force, and in most cases after national implementing legislation had also come into force.

It is also clear that corruption can occur in arms sales to developed, high-income democracies with strong institutions as well as to developing countries or those with weaker institutions. The Compendium includes cases where Austria, Belgium, Greece, Portugal, and the United States are the recipient countries. The Fat Leonard scandal in the U.S., where dozens of senior U.S. military officers were bribed by Malaysian defense contractor Francis Glenn to direct port and maintenance work for U.S. vessels toward his shipyards, is the most recent major example of such corruption in western countries and has seen the first-ever criminal conviction of a serving U.S. Admiral. (See "The 'Fat Leonard' Scandal" in WPF, 2017. This, and the other cases mentioned in the text can be accessed by following the Compendium link in endnote 2.)

Strong institutions, while not on their own sufficient to guard against bribery in arms procurement, do make a difference, however. Where such institutions and controls are absent, corruption in arms procurement can go well beyond mere bribery to encompass outright embezzlement of state funds, often through the medium of fake contracts issued for goods and services that are never, or only very partially, delivered. The ongoing Nigerian Armsgate scandal is a case in point (see "Armsgate" in WPF, 2017), where former President Goodluck Jonathan's National Security Advisor Lt. Col. Sambo Dasuki was given unchecked control over billions of U.S. dollars worth of budget and off-budget procurement funds and used them, along with a wide network of cronies in the military, government, politics, and business, to steal billions of U.S. dollars of funds. Between 2007 and 2015, as much as USD15 billion may have been looted, according to the Nigerian Economic and Financial Crimes Commission, most of it during Dasuki's tenure from 2012-2015. And this in a country whose annual official defense budget runs to about USD2 billion only. By comparison, the Fat Leonard scandal involves perhaps tens of millions of dollars, for a country with a defense budget of over USD600 billion.

Numerous cases of embezzlement and fake contracts have been uncovered also in Indonesia and Russia, although not on the same scale as in Nigeria. In one case in Russia a contract was given - in return for bribes to various officials- for the repair of the Russian Navy Cruiser, the St. Petersburg. Even though the vessel did not actually need repairs, funds went to a shell company which had mimicked the name of a real naval maintenance and repair company. The fake company did not carry out any work and, moreover, overcharged for the work it was hypothetically supposed to do. ${ }^{6}$

\section{The limits of anti-corruption efforts}

Apart from the fact of corruption itself, a second pattern that clearly emerges from WPF's work is how difficult it is to prove corruption cases in the arms business (and probably in many other domains as well) and how rare it is for serious penalties to be imposed on those engaged in corrupt activities. Part of this concerns the extremely complex nature of bribery cases, where those paying and receiving bribes do all they can to obscure the financial trails, e.g., through the use of intermediaries and shell companies. While it may be possible 
to demonstrate that a company has paid a fee to an agent that cannot be explained by any legitimate service performed, it is much harder or entirely impossible to establish the ultimate beneficiary of the payments or demonstrate a quid pro quo connected to an underlying arms deal. Many corruption cases span numerous jurisdictions: The buyer's, the seller's, the country where agents are based, the location of financial intermediaries and shell corporations, and so forth. A successful prosecution may therefore require complex inter-jurisdictional cooperation. The Compendium abounds with cases of investigations that ultimately failed to lead to convictions (or that remain ongoing, seemingly bogged down), or where convictions are overturned on appeal due to a technicality, or where convictions are secured only on minor charges with more serious charges dropped.

Typical is the case of BAE System's go-to arms agent in central Europe, Austrian Count Alfons Mensdorff-Pouilly, who was alleged to have been involved in the payment of bribes to Czech and Hungarian politicians in connection with these countries' purchase of the Gripen combat aircraft (see "Gripen Deals with the Czech Republic and Hungary" in WPF, 2017). An Austrian judge acquitted him of corruption charges, but emphasized that this was not the same as a clean bill of health on the Count's dealings — " "the whole thing stinks," commented the judge. But proof of who were the ultimate beneficiaries of Mensdorff-Pouilly's disbursements was lacking. Meanwhile, the Count was charged by the U.K.'s Serious Fraud Office (SFO) in connection with these deals but the charges were dropped in 2010 as part of a plea deal with BAE Systems. BAE received a paltry "false accounting" fine of GBP30 million in connection with a corruption case involving Tanzania, while all other charges in relation to deals with South Africa, the Czech Republic, Hungary, and Romania, were dropped in spite of the existence of ample evidence of wrong-doing.

The BAE Systems deal illustrates another reason why arms trade corruption frequently goes unpunished, or very lightly punished, namely, the political protection that those involved often enjoy in both recipient and supplier countries. On the recipient side, whether an investigation is started at all will frequently depend on the nature of the government and on the political position of those under suspicion. Where those receiving bribes retain political power, or are allied to those who hold power, they are unlikely to face investigation and may be in a position to actively obstruct or halt investigations such as when then-President Zuma of South Africa disbanded the Scorpions, an elite anti-corruption investigatory force that was pursuing the massive bribery that took place in an South African arms deal of 1999 (see "The South African Arms Deal" in WPF, 2017). In India, one sees a pattern of new governments being keen to investigate corrupt deals signed by their predecessors from the opposite side of the political divide while ignoring those of their own. ${ }^{7}$

On the supplier side, arms-producing countries are reluctant to punish companies that form a core part of their defense industrial base. The most extreme example of this is the U.K.'s cancellation of the Serious Fraud Office's investigation into BAE's Al-Yamamah arms deals with Saudi Arabia in the face of Saudi pressure (see "The Al Yamamah Deals" in WPF, 2017). But even in the U.S., which is much more willing to prosecute cases of bribery of foreign officials under the Foreign Corrupt Practices Act (FCPA), the worst any company is likely to face is a Deferred Prosecution Agreement, or DPA, accompanied by a fine and a "dressing down". The fines can be large_-BAE Systems was fined USD400 million for its failure to declare payments and its violation of the FCPA and the U.S.'s International Traffic in Arms Regulations (ITAR) in relation to Saudi, South African, Czech, and Hungarian deals - but even so this is a small fine as compared to the vast profits made by the company from their Saudi sales alone over the decades. By contrast, as noted, the U.K.'s SFO entered into a "sweetheart" deal with BAE, whereby the company paid only GBP30 million in 2010 and, moreover, was guaranteed immunity for any corrupt dealings up to that point.

For individuals involved in corruption on the seller's side prosecution is rarer still. The only case we have found in which anyone went to prison for paying bribes to foreign officials in relation to an arms deal, or for collaboration in such activities, is that of two mid-level German executives of the company Ferrostaal, for bribes in connection with submarine sales to Greece and Portugal (see "Greek Submarine Scandal" and "The Portuguese Submarine Deal" in WPF, 2017). Two much higher-level Italian executives - the former CEOs of Italian arms giant Finmeccanica (now Leonardo) and of its helicopter-making subsidiary AgustaWestland-were convicted and sentenced to jail in 2014 for bribery in relation to the sale of VVIP helicopters to India. Yet, following numerous appeals, both were ultimately acquitted (see "India VVIP Helicopter Deal" in WPF, 2017).

In contrast, in at least some cases recipient countries have sentenced bribe-takers to prison. In the Greek submarine case, a former Minister of Defense, among others, received a prison term. In the Portuguese case for which the German executives were jailed, however, no prosecutions have been successful.

There are some tentative signs that enforcement efforts are increasing. Rolls Royce, for example, was subject to a record GBP600 million fine in 2016 as part of a settlement with the U.K.'s SFO for a range of corruption cases spanning the globe in both its military and civil business (see "Rolls Royce Jet 
Engine Sales to India" in WPF, 2017). Nonetheless, this was once again a Deferred Prosecution Agreement, which is supposed to be for companies that volunteer information resulting from internal investigations. Rolls Royce did cooperate with the SFO but only after the latter had already uncovered ample evidence of wrong-doing. The message to other companies is that "so long as you cooperate after you are caught, you will get a DPA." This hardly provides a strong deterrent to corruption.

The German and Italian cases do illustrate some effort by national prosecutors to hold companies accountable for their actions. (Ferrostaal paid a substantial fine in relation to the affair). Meanwhile in France, investigations are continuing into several older corruption cases and prosecutors have begun investigations into the much more recent sale of submarines to Brazil in 2014. This is in contrast to the more common pattern where corruption is only investigated, if at all, many years after the event.

It is possible, then, that European arms producing companies are beginning to take their obligations under the OECD convention, and the national laws implementing it, at least semi-seriously. However, one current case in the U.K. may prove to be an important test of this proposition: For deals stretching back to the 1970s, the SFO has been investigating allegations of corruption in contracts with the Saudi Arabia National Guard by the company GPT Project Management, a U.K. subsidiary of Airbus, for the supply and support of communications equipment. The corruption allegations, relating in particular to the most recent contract signed in 2010, arose from information provided by an ex-Ministry of Defense (MoD) whistle blower in Saudi Arabia who was then working for GPT as part of a joint company-MoD team implementing the project. Several GPT employees have been arrested and questioned in connection with the case. Reports suggest that the SFO is nearing the point where charges could be brought but is awaiting permission to proceed from the top U.K. law officer, the Attorney General (see "GPT and the Saudi National Guard" in WPF, 2017). The question is, will the U.K. government once again, as in the Al-Yamamah case, prioritize the arms trade with Saudi Arabia over the rule of law and halt the investigation (or leave it hanging without outcome), or will it allow prosecutions to take place in spite of the potential consequences for business with the U.K. arms industry's number one foreign customer?

\section{Corruption as industrial policy}

In understanding why corruption in the arms trade is so prevalent, it is important to consider the political-economic structure of the global arms trade that makes exporters so willing to pay bribes to secure deals and governments willing to go easy on companies that do so, or even to actively collaborate in such activities.

The arms industry is much less concentrated than comparable industries with similar levels of technology and capital requirement. ${ }^{8}$ While the market for major civilian aircraft is dominated by just two players, Boeing and Airbus, the market for major combat aircraft includes Boeing, Lockheed Martin, Northrop Grumman, United Aircraft Corporation (Russia), AVIC (China), Airbus (trans-European), BAE Systems (UK), Dassault (France), Mitsubishi Heavy Industries (Japan), and Saab (Sweden). In this, and other sectors, middle-sized players are seeking to keep autonomous technological and production capabilities going that would not be viable in a fully competitive market if price and quality, rather than the national base of manufacture, were the only issues. But the desire on the part of countries to develop and maintain autonomous arms production capabilities as a means of preserving some strategic autonomy and security of supply appears to be almost universal. Even those countries that cannot realistically aspire to producing a wide range of advanced major armaments - such as smaller European producers, or the likes of Australia, Singapore, Indonesia, and Canada-still seek to maintain some sort of arms industry, whether based on licensed production, specialization in particular types of system, fitting into the supply chains of major producers, or some combination thereof. ${ }^{9}$

For the major European producers, "national champions" such as BAE Systems (UK), Dassault, Thales, and Naval Group (France), Leonardo (Italy), ThyssenKrupp (Germany), Saab (Sweden), and the French-German Airbus Group exercise significant influence over government policy as a result of their position at the heart of their countries' defense industrial base and are monopoly domestic suppliers either in a particular domain of weapons systems or, in the case of BAE, Leonardo, and Saab, in multiple domains. This influence is exercised via a "revolving door" arrangement between government (especially the defense and sometimes trade ministries) and industry, secondments from industry to government, representation on policy committees, and frequent high-level access of corporations to top government officials and politicians. One author quotes a Swedish defense procurement agency official likening the relation of the Swedish government to Saab to that of "a parent and child." Presidents, prime ministers, and even royalty will often make lobbying for arms sales a major priority of overseas visits. ${ }^{10}$

For most producer countries, domestic demand is insufficient to maintain viable capabilities, especially the most advanced, and therefore export dependence is high. This is true 
of all the major West European producers as well as of Russia. Up until the mid-2010s, indeed, the Russian arms industry was almost entirely export-dependent. (Today, increasing levels of domestic demand are complementing export sales.) Much is often made of the role of exports in reducing unit costs due to scale and learning effects in the production of major systems. While learning effects are undoubtedly highly significant for major systems with relatively short production runs, the extent to which exports reduce the cost to national governments is uncertain as this will depend on whether the government will recoup these gains from the exporting company. In the U.K., for example, BAE Systems enjoys sole source contracts for over 90 percent of its sales to the U.K. government. In such contracts, a standard profit rate is applied over costs and does not take into account potential future exports. Thus, the U.K. government essentially pays the costs of research and development plus a profit margin up-front, allowing BAE to enjoy profits from export sales and the benefits of reduced unit costs from longer production runs. ${ }^{11}$

However, the key question for governments concerns not so much unit costs as whether national champions will be able to maintain their technological and production capabilities for the most advanced systems at all. Even countries like the U.K. and France renew major platforms such as aircraft and ships only every few decades, so long gaps between these domestic orders are common. Without exports, production lines would have to be closed down or mothballed, key employees would leave, and thus key know-how and capabilities could be lost and become difficult to reconstitute. For companies, exports represent major profit opportunities, but for governments they also represent the means of ensuring the continued capability of their defense industrial base to develop and produce new weapons systems and preventing a growing dependence on imports.

The problem for exporters is that major deals for systems such as combat aircraft, submarines, major surface combatants, and the like are rare, with most countries making such purchases once or twice in a generation. Moreover, for the majority of countries that do not face urgent conventional military threats, the purchase of an entirely new advanced system is often a luxury rather than a necessity: Like someone deciding on buying a car, keeping the current one going for a couple more years or buying a good used car are viable alternatives.

For example, over the period 2008 to 2017, a total of 64 deals were agreed worldwide (including some selected but not definitively ordered) for exports of 1,739 major combat aircraft. However, 25 of these 64 deals were by the U.S., and 21 by Russia, leaving six other countries - China, France, Italy,
Corruption is not so much an aberrant feature of arms deals but actually a facet of defense industrial policy.

South Korea, Sweden, and the U.K.-fighting over the remaining 18 deals for 465 planes. (Plus Germany, which also produces Eurofighter Typhoons but which did not win any deals during this period). In the naval sphere, a total of 72 submarines were ordered by 16 countries from just 5 suppliers: Germany (32), France (17), China (11), Russia (9), and South Korea (3). For major surface warships, 95 were ordered from 11 suppliers: China (20), France (16), South Korea (13), Italy (9), Netherlands (8), the U.S. (8), Germany (7), Russia (6), Turkey (4), the U.K. (3), and Spain (1). In other words, the deals are few and far between, and the workloads they generate for the producers of these complex systems are limited. ${ }^{12}$

Thus, the international arms trade tends to be a buyer's market even when international tensions are fairly high. Numerous sellers are competing for a limited number of deals, where buyers have other options. Failure to make one of the handful of sales opportunities coming up over a period of a few years may threaten the viability of national capabilities. The incentive for exporters to do whatever it takes to win these crucial orders, up to and including bribery, is therefore great as is the incentive for their national governments to turn a blind eye to such practices, or at the very least to go easy on them when discovered. Corruption is, in this sense, not so much an aberrant feature of arms deals, but actually a facet of defense industrial policy.

\section{Does the U.S. bribe less? (And if so, why?)}

A large proportion of the cases WPF has examined involve major European arms producers as exporters. Russian arms sales, too, have in a number of cases been the subject of corruption allegations, although investigations have only ever come from the buyer's end. There is no indication that Russian authorities have opened any investigation into such deals.

In contrast, while some cases involving U.S. arms exports have emerged and been prosecuted by the Department of Justice and/or the Securities and Exchange Commission, these have been relatively minor and few in number in comparison to the huge size of U.S. arms exports - excepting, that is, cases such as BAE, and another involving Brazilian company Embraer, where foreign-based companies have been prosecuted by U.S. authorities on the basis of their possession of U.S. subsidiaries and listing on U.S. stock exchanges, thus making them subject to U.S. reporting requirements.

It is possible that U.S. companies have become more adept at disguising corrupt payments and avoiding detection, but it 
seems likely that the infrequency of cases reflects a lesser tendency for U.S. arms exporters to engage in significant bribery. (This does not exclude that some cases may remain undetected, in addition to those that have been investigated). There are a number of reasons why this might be the case, some of which relate to the defense industrial considerations discussed above and to the U.S.'s unique place in the global arms trade and in international security more broadly.

First, in the FCPA, the U.S. has long-standing legislation against bribery of foreign officials. Moreover, anti-corruption legislation is stronger than in Europe, with ITAR requiring companies to report all commissions, fees, and political contributions made in connection with foreign arms sales. While almost all exporters report zero such payments, the requirement makes it easier to establish malfeasance, in that it is necessary only to establish that an unreported payment was made rather than to prove corrupt intent or to identify the ultimate beneficiaries of the payment. ${ }^{13}$

Second, the U.S. has extremely strong political and security ties with many of its major customers such as Japan, South Korea, Saudi Arabia, and Australia, and these countries are inclined to turn to the U.S. as their principal arms supplier as a way of maintaining this relationship and effectively seeking to purchase continued U.S. security guarantees along with the weaponry. For some of these countries, interoperability with U.S. forces and indeed with their own existing U.S. equipment may be another motivation. (Saudi Arabia appears to have no such concerns, buying a hybrid air force from several different suppliers.) Thus, the U.S. government does much of the work involved, especially in relation to government-to-government Foreign Military Sales agreements, greatly reducing the need for companies to employ dubious independent marketing strategies.

Third, the U.S. domestic market is by far the largest arms market in the world and an enormous and essentially guaranteed source of profit for the major U.S. arms manufacturers. Not that these companies do not also seek whatever export opportunities may come their way, but the lesser degree of export dependence of U.S. companies means that the U.S. government has less incentive to turn a blind eye to bribery as a means of preserving its defense industrial base. Indeed, this lower export dependence may be one of the reasons why the U.S. is willing to maintain stronger legislation and investigatory practices against arms trade corruption. Moreover, U.S. companies seem to devote the bulk of their lobbying and influence-peddling activities to the much larger domestic market, where unlimited campaign contributions to legislators are entirely legal. Thus, a risk-benefit analysis of breaking the law through foreign bribery may be much less appealing. ${ }^{14}$

\section{Corruption as a political tool}

Politics is an expensive business as election campaigns become ever more costly. Where strict limits to election spending exist, as in France for example, candidates may well seek off-budget sources of funding. A high profile recent case is that of the current French investigation into former President Nicholas Sarkozy, who, it is alleged, received up to EUR50 million in payments from former Libyan dictator Moammar Gaddafi. Aside from regular election expenses, the costs of political success can include internal party competition, building up local party structures (cultivating loyalty and support), and sometimes more nefarious activities such as vote buying, paying local "enforcers", maintaining a patronage network that rewards loyal supporters, and so forth. All of this requires a substantial political budget for leading politicians, some of which may be obtained through legal channels but some of which may require alternative, illicit sources of funding. ${ }^{15}$

The arms trade is a highly political business, being tightly connected to national security. Governments are the prime customers, and decisions on major acquisitions tend to involve leading political figures as well as procurement officials and military officers. At both the buyer's and seller's ends, senior politicians may play a decisive role. Arms deals, therefore, can provide a perfect opportunity for politicians to fund their political budget. Hence, arms trade corruption frequently has a political motivation, beyond personal enrichment. The Compendium includes numerous cases where bribes paid in connection with arms sales have gone to finance political parties or individual candidates' election campaigns. In many cases, bribes are very widely distributed, not just to the prime decisionmakers but also to those who could potentially act as "spoilers" and need their cut and to those who form part of top politicians' patronage networks. ${ }^{16}$

\section{Offsets}

One of the clearest symptoms of the perennial buyer's market in the arms trade is the prevalence of offsets, a nearly universal feature in major arms deals. Offset agreements require exporters to make investments and counterpurchases in the importing country to offset the foreign currency cost of the deal. Offsets can be direct, such as local production of some or all of the equipment, subcontracting, and technology transfer, or indirect, where investments and counterpurchases may be in sectors unrelated to the deal or in the arms industry in general. Offsets are largely unknown in other industries (indeed prohibited by the WTO convention on government procurement, for those who are signatories). But in 
international arms deals, buyers are able to demand them, and sellers - even the U.S. - have little choice but to accede to these requests if they are to compete. ${ }^{17}$

Offsets create a fertile channel for corruption in arms deals and are particularly well-suited to political corruption as they can be an effective means for politicians to reward supporters without offering direct bribes. Because offsets imply a discretionary opportunity for the selling firm or the buying government to pick and choose partners in the buying state, they create lobbying incentives for potential partners. Allotting offset investments can serve as a mode of patronage, that is, rewarding political supporters and their aligned business interests. Offset arrangements, even those for indirect offsets, are typically highly opaque, with details of individual contracts rarely made public unless it is in the interests of one party to do so. Thus, it is much harder for the public and regulatory authorities to scrutinize just who is benefitting from offset investments and contracts. One example of how this can operate is in an South African arms deal, where then-Defense Minister Joe Modise bought shares in a company, Conlog, which shortly afterward received offset investments and contracts from BAE Systems as part of the deal. ${ }^{18}$

Offsets may provide an attractive channel for corruption in arms deals in general (political or otherwise) as they add an extra layer of obscurity and deniability to the process. A large commission payment to an agent who provides no obvious service to justify the payment is inherently suspicious. But an offsets package, negotiated without transparency, and where many of the specific offset investments are not made public, may not give rise to clear grounds for suspicion, such as large payments of a dubious nature. Thus, decisionmakers might steer offset negotiations toward subcontracting that they know they or their allies will benefit from, while the exporting company can maintain plausible deniability. Even if the corrupt nature of the transaction is discovered, it may be hard to demonstrate that the exporting company has been culpable, for example through lack of due diligence. ${ }^{19}$

In at least nine Compendium cases in WPF (2017) offsets have been identified as a vehicle of corruption. This likely only scratches the surface, given the difficulties in cataloguing offset arrangements and identifying who may have benefitted from them.

\section{Retrocommissions}

A specific example of corruption opportunities is the phenomenon of so-called retrocommissions associated with several French arms sales. In particular, in the case of sales of submarines to Pakistan and of frigates to Saudi Arabia, a portion of these commissions was funneled back to fund the
Regarding arms trade-related corruption, the law enforcement and national security functions of government may be working at cross-purposes to each other, one seeing it as a criminal investigation, the other as a matter of fundamental national defense interests.

1995 presidential election campaign of then-Prime Minister Edouard Balladur (see "l'Affaire Karachi" in WPF, 2017). The key agent for some of these deals, French-Lebanese arms broker Ziad Takieddine, is also involved in the current Sarkozy investigation. He claims to have personally delivered suitcases full of Gaddafi money to Sarkozy. The corruption scandal that brought down former German Chancellor Helmet Kohl also involved retrocommissions on arms sales, mostly used to fund intra-party political competition to support Kohl's faction within the Christian Democrat Party (see "The CDU Party Funding Scandal" in WPF, 2017). ${ }^{20}$

\section{Conclusions}

Understanding the systemic nature of arms trade corruption is crucial to understanding why and how it operates and to our prognosis and prescriptions for reform. On the exporter side, the role of arms export deals as a means of maintaining defense industrial capabilities in medium or even medium-large producers gives a powerful incentive to turn a blind eye toward the means deployed to achieve them, including corruption, and to protect companies from the legal consequences of such actions. The law enforcement and national security functions of government may therefore be working at cross-purposes to each other, one seeing it as a criminal investigation, the other as a matter of fundamental defense interests.

On the side of the bribe recipients - in the buyer, and sometimes also the seller country-if the motivations for seeking kickbacks in connection with arms deals is political as well as personal (although the latter is undoubtedly a factor in many cases), then the driving forces behind arms trade corruption may be deeply embedded in the structure of political power and competition in a country rather than merely and simply being a function of the individual greed of particular leaders and decisionmakers. A "new broom" may come in with a genuine desire to reduce corruption but will be subject to the same political imperatives to obtain reliable sources of political finance as any predecessor. The tendency to pursue corruption scandals by previous administrations while turning a blind eye to, or actively collaborating in, corruption in one's own party is therefore likely to be a strong one.

The prognosis is not completely without hope. In several countries, including the U.S. and the U.K., a strong consensus appears to be emerging across the political spectrum on the 
need to strengthen financial transparency and to combat corruption, money laundering, and other financial crimes (including transparency on the beneficial ownership of companies and foundations) to make it harder for corrupt dealings to hide behind anonymous shell companies. One of the reasons for this is that vulnerabilities in the financial system can be exploited in numerous ways: to facilitate corrupt arms and other deals, certainly, but also for money laundering in support of terror and organized crime, and by oligarchs and sanctioned regimes and individuals to launder corrupt gains and evade sanctions.

While new measures may make arms trade corruption easier to detect, they do not deal with the problem of political will to prosecute companies and individuals who engage in it. Repeated exposure may help, but to seriously tackle arms trade corruption would require addressing the underlying political and defense policy forces that drive it.

\section{Notes}

For comments on a draft version of this article I thank participants at the SIPRI arms industry workshop, March 2018, as well as an anonymous reviewer.

\section{Long recognized: See, e.g., Roeber (2005).}

2. Compendium: See WPF (2017). The Compendium of Arms Trade Corruption (http://sites.tufts.edu/corruptarmsdeals) was first published online in May 2017. New entries have continued to be added up to April 2018 and existing entries continue to be updated as new information becomes available about the cases. The Compendium, and its component entries, is nonetheless referred to throughout this article as WPF (2017), based on the original date of publication.

3. U.S. corruption complaints: Roeber (2005). Pattern of systematic corruption: Feinstein (2011). High to Critical ratings: TI (2015). In war contexts: See, e.g., Chayes (2015).

4. On arms offsets, see Brauer and Dunne (2004; 2011). Collins (1996, p. 5) writes: "Much of the existing discussion of procurement offsets relates to the exceptions found in many national and international legal systems in favour of defence procurement, the sector in which offsets remain the most popular and where prohibitions in international and national laws do not apply."

5. Systemic, routine nature: Guisnel (2011). Previous names of DCNS include DCN and Direction des Constructions Navales.

6. Russian cruiser: Beliakova and Perlo-Freeman (2018).

7. Zuma: The charges, dropped just before he assumed the presidency, were reinstated soon after Zuma left office.

8. Dunne and Smith (2016). Some other recent works that give a good overview of the structure of the contemporary arms industry include Bitzinger (2009a, 2009b) and Tan (2010).
9. Brauer (2000) concluded that "countries that can produce arms (potential) do produce arms (actual)." For a relatively recent overview of the modern global arms industry, and the place of different nations within the international arms production hierarchy, see Bitzinger (2009a, 2009b).

10. One author: Åkerström (2016, p. 195). Presidents, prime ministers, and royalty: See, for example, Tony Blair's promotion of U.K. arms sales to South Africa (Plaut, 2007), Prince Charles' promotion of U.K. arms sales to Saudi Arabia (Norton-Taylor, 2014), and Donald Trump's promotion of U.S. arms sales to numerous customers (Hartung, 2018). See also Feinstein (2011), Guisnel (2011).

11. Export dependence is high: Overseas sales no longer are a supplemental form of income; they are increasingly critical to the health and survival of the defense industrial base. Reducing unit costs: E.g., Chalmers, et al. (2002) estimated an annual saving to the U.K. MOD of GBP160 million per year as a result of unit cost savings from exports. In such contracts: There is a small "commercial exploitation levy" applied by the government to exports, but this recoups only a tiny proportion of R\&D costs, amounting to an average of GBP9.5 million over the years 2012/13 to 2014/15 (see Perlo-Freeman, 2016).

12. All information taken from SIPRI's Arms Transfers Database. Second-hand sales were excluded, unless substantially modernized before delivery, as these do not generate new work. Major surface combatants include frigates, corvettes, and amphibious assault and landing ships. No contracts for aircraft carriers or destroyers were signed during this period, although a few were in the preceding decade.

13. On this, see, e.g. Pelak (2017).

14. Lesser degree of export dependence: U.S. spending on procurement as part of national defense spending consistently exceeds USD100 billion while military R\&D spending consistently exceeds USD50 billion (Office of Management and Budget, 2018). The vast majority of this is spent on the U.S. defense industry, as is a significant portion of the Operations and Maintenance budget. By contrast, U.S. arms exports do not exceed USD30 billion per year (Perlo-Freeman, 2018).

15. Sarkozy: Arfi and Laske (2018). Political budget: de Waal (2015).

16. Numerous cases: Such cases are discussed in detail in Liang and Perlo-Freeman (2018).

17. Prohibited: See Art. XVI, Agreement on Government Procurement, available at www.wto.org. For background, see https:/www.wto.org/english/tratop_e/gproc_e/gpa_overview _e.htm.

18. See "The South African Arms Deal" in WPF (2017).

19. For a discussion of some of these issues, see for example Fluka, Muravska, and Pyman (2012) and Weissman (2014).

20. Suitcases: Arfi and Laske (2018). 
References

Åkerström, L. 2016. Den Svenska Vapenexporten [The Swedish Arms Trade]. Stockholm: Leopard Förlag.

Arfi, F. and K. Laske. 2018. "Argent libyen: Sarkozy est mis en examen pour corruption.” Mediapart. 23 March 2018. https://www.mediapart.fr/journal/international/ 210318/argent-libyen-sarkozy-mis-en-examen?onglet=full.

Beliakova, P. and S. Perlo-Freeman. 2018. "Corruption in the Russian Defense Sector.” World Peace Foundation. May. https://sites.tufts.edu/wpf/files/2018/05/

Russian-Defense-Corruption-Report-Beliakova-Perlo-Fre eman-20180502-final.pdf.

Bitzinger, R., ed. 2009a. The Modern Defense Industry: Political, Economic, and Technological Issues. Santa Barbara, CA: Praeger Security International.

Bitzinger, R. 2009b. "Introduction: Challenges Facing the Global Arms Industry in the 21 st Century." Chapter 1 in R. Bitziner, ed. The Modern Defense Industry: Political, Economic, and Technological Issues. Santa Barbara, CA: Praeger Security International.

Brauer, J. 2000. "Potential and Actual Arms Production: Implications for the Arms Trade Debate." Defence and Peace Economics. Vol. 11, No. 3, pp. 461-480. https://doi.org/10.1080/10430710008404961

Brauer, J. and J. Paul Dunne. 2004. Arms Trade and Economic Development: Theory, Policy, and Cases in Arms Trade Offsets. London: Routledge. https://doi.org/10.4324/9780203392300

Brauer, J. and J. Paul Dunne. 2011. "Arms Trade Offsets: What do We Know?" pp. 243-265 in C.J. Coyne and R.L. Mathers, eds. The Handbook on the Political Economy of War. Cheltenham, UK: Elgar. https://doi.org/10.4337/9781849808323.00022

Chalmers, M., N.V. Davies, K. Hartley, and C. Wilkinson. 2002. "The Economic Costs and Benefits of UK Defence Exports." Fiscal Studies. Vol. 23, No. 3, pp. 343-367. https://doi.org/10.1111/j.1475-5890.2002.tb00064.x

Chayes, S. 2015. Thieves of State: Why Corruption Threatens Global Security. New York: W.W. Norton.

Collins, D.A. 1996. "Government Procurement with Strings Attached? The Uneven Control of Offsets by the World Trade Organization and Regional Trade Agreements." Asian Journal of International Law. Vol. 8, No. 2, pp. 301-321. https://doi.org/10.1017/S2044251316000278

De Waal, A. 2015. The Real Politics of the Horn of Africa. London: Polity Press.

Dunne, J.P. and R. Smith. 2016. "The Evolution of Concentration in the Arms Market." The Economics of Peace and Security Journal. Vol. 11, No. 1, pp. 12-17. https://doi.org/10.15355/epsj.11.1.12

Feinstein, A. 2011. The Shadow World: Inside the Global Arms Trade. New York: Farrar, Straus and Giroux.

Fluka, L., J. Muravska, and M. Pyman. 2012. "Due Diligence and Corruption Risk in Defence Industry Offset Programmes." Transparency International Defence \&
Security. February 2012. http://ti-defence.org/wp-content/ uploads/2016/03/2012-02_DueDiligenceAndCorruptionR iskInOffsets.pdf

Guisnel, J. 2011. Armes de Corruption Massive: secrets et combines des marchands de canons. Paris: La Découverte.

Hartung, W.D. 2018. "Donald Trump: Gunrunner for Hire." The Nation. 14 August 2014. https:/www.thenation.com/ article/donald-trump-gunrunner-for-hire/

Liang, X. and S. Perlo-Freeman. 2018. "Arms Trade Corruption and Political Finance." World Peace Foundation. July 2018. https://sites.tufts.edu/wpf/armstrade-corruption-and-political-finance/.

Norton-Taylor, R. 2014. "The Future British King, Saudi Princes, and a Secret Arms Deal." The Guardian. 24 February 2014. https:/www.theguardian.com/uk-news/ defence-and-security-blog/2014/feb/24/arms-gulf-princecharles.

Pelak, S. 2017. "A Few Observations on Part 130 of ITAR." Presentation given at "Tackling Corruption in the Arms Trade" Forum on Arms Trade. 2 November 2017. https://www.forumarmstrade.org/events.html\#2017Nov2.

Perlo-Freeman, S. 2016. "Special Treatment: UK Government Support for the Arms Industry and Trade." SIPRI/Campaign Against Arms Trade. November. https:/www.sipri.org/publications/2016/other-publicatio ns/special-treatment-uk-government-support-arms-indust ry-and-trade.

Perlo-Freeman, S. 2018. "How Big is the International Arms Trade?" World Peace Foundation Occasional Paper. July 19 2018. https://sites.tufts.edu/wpf/files/2018/08/How-big -is-the-International-Arms-Trade-20180725-f.pdf.

Plaut, M. 2007. "Blair Role in SA Arms Contract." BBC News. 31 May 2007. http://news.bbc.co.uk/1/hi/uk_politics/ 6707369.stm.

Roeber, J. 2005. "Parallel Markets: Corruption in the International Arms Trade." Campaign Against Arms Trade. Goodwin Paper No. 3. https://www.controlbae.org.uk/ background/parallel_markets.pdf.

U.S. Government Office of Management and Budget. 2018. Historical Tables. Table 3.2, pp. 60-73. https://www.whitehouse.gov/omb/historical-tables/

Tan, A., ed. 2010. The Global Arms Trade: A Handbook. London: Routledge.

[TI] Transparency International Defence \& Security. 2015. Government Defence Anti-Corruption Index. http://government.defenceindex.org.

Weissman, H. 2014. "Offset Deals can Pose High FCPA Risks for Defense Industry." Global Compliance News. 2 December 2014. https://globalcompliancenews.com/offsetdeals-can-pose-high-fcpa-risks-for-defense-industry/.

[WPF] World Peace Foundation. 2017. A Compendium of Arms Trade Corruption. https://sites.tufts.edu/ corruptarmsdeals/. 